\title{
Self-Awareness of LGBT People Based on Personality Typology
}

\author{
Rida Yanna Primanita ${ }^{1}$,Yuninda Tria Ningsih ${ }^{2}$, Zakwan $_{\text {Adri }}{ }^{3}$ \\ \{yannaprimanita@fip.unp.ac.id ${ }^{1}$,yunindatrianingsih21@gmail.com², \\ zakwan@mail.ugm.ac.id $\left.{ }^{3}\right\}$ \\ Jurusan Psikologi Fakultas Ilmu Pendidikan, Universitas Negeri Padang, Bukittinggi, Indonesia ${ }^{1,2,3}$
}

\begin{abstract}
This study aims to find the description of self-awareness, description of personality typology, and the difference of self-awareness based on personality types in LGBT people. This is a quantitative comparative research. The population of this research is LGBT people in West Sumatera Province Indonesia. Snowball sampling was used in this study. Participants of this research were 224 people from 9 cities in West Sumatera Provinces. Personality typology used two instruments: Millon Personality Type Inventory developed by Airin Triwahyuni for personality typology and Self-Awareness scale developed by the researcher for measuring self-awareness. The data were analyzed using one-way ANOVA technique. The result showed there is significant difference of self-awareness of LGBT people based on personality type, at the level of $p=0.03$ $(\mathrm{p}<0.05)$.
\end{abstract}

Keywords. LGBT, Millon personality type, personality, self-awareness, Sumatera Barat Province

\section{Introduction}

The social issue of LGBT (Lesbian, Gay, Bisexual, Transgender) has become a worrying and still unacceptable phenomenon in Indonesian people. The data from AIDS Eradication Commission of West Sumatera mentioned that a number of 82 people are suffering positive for HIV/AIDS. Most cases indicate that male-to-male sexual intercourse becomes the dominant cause for those HIV/AIDS cases. The term of LGBT (Lesbian, Gay, Bisexual dan Transgender) is a phrase used to represent the group with non-heterosexual sexual orientation [1]. Lesbian is a kind of group which has female-to-female sexual orientation. Lesbian couple usually will share the role whether as the male and female, female and female and even male and male although they are genetically female. While, gay is a kind of group of male-to-male sexual orientation. A gay male is usually sexually interested in male. As the lesbian, a gay male also shares roles with his spouse in making sexual intercourse. On the other hand, bisexual is interested in both gender, male and female [2]. And, transgender is a term for a child or adult who think that their gender are psychologically contrary to the anatomy they have and continuously show inconvenience to his body and gender [3].

Although their existence is not accepted, as it breaks norms, culture and religious belief, and also health and social norms, the number of people of LGBT tends to increase during the time and some of them exhibit their gender identity and sexual status without worrying the 
environmental judgments in the society. Not only personally, the number of existing group of LGBT keeps increasing in recent years. It proves that many of them have recognized the ability to know and realize their potentials and environment among them. Through the community, these LGBT groups try to struggle their rights as the citizen. But, this struggle has not made the positive results for them as the law system in this country has not approved their wants. Indonesian legal system admits male and female gender only.

LGBT cases have become the core problems in society because they exhibit the inproper sexual orientation with social values and norms. Sexual orientation is defined as the erotic tendency of people with the similar gender nor different one with him/her [4]. In certain people, sexual orientation is a line with social norms and values, but for the others are not. It is assumed that the mismatch in identifying and realizing the processes occurring in themselves. This is called self-awareness. Solso, Maclin, \& Maclin (2007) mentioned that individual awareness on the events surrounding and cognitive events such as memory, mind, feeling and physical sensations. Goleman (2001) explained that self-awareness is the continuous attention to inner process, self reflection, mind observation and experience including emotion. Further, Goleman (2001) mentioned that individual with higher awareness can recognize emotion and its impacts, including to realize the relation between emotion and the performance. Afriani \& Primanita (2019) find the LGBT people have self-awareness in medium category, that mean LGBT people in certain situations can be self-aware of themselves but in other situations they are fail to self-aware themselves.

One reason why a person behaves is about how the person realizes, thinks and has the standpoint about the need and status of sexuality. Status of sexuality is influenced by both internal and external factors, including personality. Personality is a complex, general related to traits, attitude and habits which are exhibited indirectly [8]. Some LGBT actors show different behaviors for intra and interpersonal relation. For interpersonal relation, they look manipulative, paranoid and some others pursue attention in making personal relation with others. While, for intrapersonal relation, some of them seem to be arrogant, selfish, cannot be strict to his own principles to meet others' wants, feeling guilty. These behaviors are often considered that they cannot be classified to any type of personality

\section{Ease Of Use}

Description of self awareness, personality types, and differences in self awareness based on personality types in LGBT people in West Sumatra. To compile an intervention program that is in accordance with the characteristics of LGBT people. This research will be the reference data of intervention programs based on personality profiles of LGBT people in West Sumatra. Which is no specific intervention program for LGBT people.

\section{Methods}

This is a quantitative-comparative study. The study used snowball sampling, with 224 people of LGBT participating from 9 towns in West Sumatera Province, Indonesia. Personality typology was measured using Millon Personality Type Inventory (MPTI) (validity 0.3; reliability $(0.749-0.848)$ developed to to measure expressive act, interpersonal conduct, cognitive style, regulatory mechanism, self-image, object representation, morphologic 
organization and mood/temperament. MPTI has 14 types of personality: negativistic, borderline, compulsive (ambivalent), sadistic, melancholic, masochistic (discordant), antisocial, paranoid, narsicistic (independent), dependent, histrionic (dependent), schizotypal, schizoid, avoidant (detached). MPTI is a YES or NO answer scale with 254 questions (249 on personality, 5 for control). Self-awareness was measured using Self-Awareness Scale (validity, 0.25 ; reliability 0.847 ). This is a likert scale with 4 options of answer. The data were analyzed using one-way ANOVA.

\section{Result}

Based on the data, results indicate that the number of participants with ambivalent personality is $111(49.5 \%)$, discordant 13 respondents $(5.8 \%)$, independent 45 respondents (20.1\%), dependent 34 respondents $(15.2 \%)$, and detached 21 respondents $(9.4 \%)$. The data are described as follows:

Table 1. Respondents

\begin{tabular}{|c|c|c|c|c|c|}
\hline No & Personality & Types of Personality & Amount & Total & Percentage \\
\hline \multirow[t]{3}{*}{1} & Ambivalent & Negativistic & 4 & 111 & $49.5 \%$ \\
\hline & & Borderline & 14 & & \\
\hline & & Compulsive & 93 & & \\
\hline \multirow[t]{3}{*}{2} & Discordant & Sadistic & 5 & 13 & $5.8 \%$ \\
\hline & & Melancholic & 4 & & \\
\hline & & Masochistic & 4 & & \\
\hline \multirow[t]{3}{*}{3} & Independent & Antisocial & 10 & 45 & $20.1 \%$ \\
\hline & & Paranoid & 11 & & \\
\hline & & Narcissistic & 24 & & \\
\hline \multirow[t]{2}{*}{4} & Dependent & Histrionic & 17 & 34 & $15.2 \%$ \\
\hline & & Dependent & 17 & & \\
\hline \multirow[t]{4}{*}{5} & Detached & Avoidant & 15 & 21 & $9.4 \%$ \\
\hline & & Schizotypal & 4 & & \\
\hline & & Schizoid & 2 & & \\
\hline & Total & & & 224 & $100 \%$ \\
\hline
\end{tabular}

The self-awareness difference among the respondents can be classified into 3 three: high, middle, low. The table below may explain the categorization of self-awareness among the respondents in this study.

Table 2. Categorization Of Self-Awareness

\begin{tabular}{llllll}
\hline No & Formula & Score & Categorization & \multicolumn{2}{c}{ Subject } \\
\cline { 5 - 6 } & & & High & \% \\
\hline 1 & $(\mu+1,0 \sigma) \leq X$ & $90 \leq X$ & 74 & $33.04 \%$ \\
2 & $(\mu-1,0 \sigma) \leq X<(\mu+1,0 \sigma)$ & $60 \leq X<90$ & Middle & $\mathbf{1 5 0}$ & $\mathbf{6 6 . 9 6 \%}$ \\
3 & $X<(\mu-1,0 \sigma)$ & $X<60$ & Low & 0 & $0 \%$ \\
& Total & & & 224 & $100 \%$ \\
\hline
\end{tabular}

Based on the category above, as many as 74 respondents of LGBT (33.04\%) have high self-awareness. While, 150 other respondents (66.96\%) are categorized into middle selfawareness. And, no respondent is categorized in low self-awareness. Based on Self-Awareness aspects, It can be that emotional awareness aspect has 76 respondents $(33.93 \%)$ are in high category, 147 respondents $(65.62 \%)$ in middle category and 1 respondent $(0.45 \%)$ in low category. In self-concept aspect, as many as 114 respondents $(50.89 \%)$ are in high category, 
107 respondents $(47.77 \%)$ in middle category, and 3 respondents $(1.34 \%)$ in low category. Then, for self-esteem category, 97 respondents $(43.30 \%)$ are grouped into high category, 125 respondents $(55.81 \%)$ in middle category, and 2 respondents $(0.99 \%)$ in low category. In multiple selves category, 94 respondents $(41.96 \%)$ are in high category, 127 respondents $(56.70 \%)$ in middle category and 3 respondents $(1.34 \%)$ in low category.

The difference of self-awareness based on the personality type is also differentiated into 3 categorizations: high, middle and low. It can be inferred that 49 respondents $(21.88 \%)$ have the ambivalent personality with high self-awareness, and 62 respondents $(27.68 \%)$ in middle selfawareness. No respondent in low self-awareness. 4 respondents $(1.78 \%)$ are grouped into discordant personality in high category. While, 9 respondents $(4.02 \%)$ in middle category and no respondent in low category. In independent personality, 10 respondents $(4.46 \%)$ in high category, 30 respondents $(13.39 \%)$ in middle and 5 respondents in $(2.23 \%)$ in low category. For dependent personality, 9 respondents $(4.02 \%)$ are in high category, 24 respondents $(10.71 \%)$ middle and 1 respondent $(0.45 \%)$ in low category. In detached personality, 2 respondents $(0.89 \%)$ in high category, 18 respondents $(8.04 \%)$ in middle one and 1 respondent $(0.45 \%)$ in low category.

LGBT people with Ambivalent personality have 2 aspects of self-awareness in middle level, they are: emotional awareness (61 participants, or 54.95\%) and multiple selves (58 participants or $52.25 \%$ ). While, two other aspects are in high category, self-concept (64 participants or $57.66 \%$ ) and self-esteem (57 participants or $51.35 \%$ ). LGBT people with discordant have three aspects of awareness are in middle catrgory: self-awareness, which consists of emotional awareness (10 participants (76.9\%), self-esteem 7 participants (53.8\%), dan multiple selves 8 participants $(61,5 \%)$. While, for self-concept aspects 7 participants $(53.8 \%)$ are in high category. LGBT people with independent personality have middle category in 3 aspects: self-awareness, which consists of emotional awareness $(77.7 \%)$, self-esteem $(60 \%)$, and multiple selves $(62,2 \%)$. While, in self-concept aspect $(51,1 \%)$ in high category. LGBT people with dependent personality are in high category for self-awareness aspect. For emotional awareness aspect (67.65\%), self-concept aspect (52.94\%), self-esteem aspect (64.71\%), and multiple selves $(61.76 \%)$. All aspects of self-awareness inparticipants of LGBT people with detached personality are in middle. Emotional awareness concept has $58.71 \%$, selfconceptdengan jumlah 17 orang (80.95\%), self-esteem aspect $(66.67 \%)$, and multiple selves aspect $(57.76 \%)$.

Test of Normality for self-awareness variable was done with Kolmogorov Smirnov dan Asym.sig score. asym.sig score for self-awareness variable and all five personality is higher than 0.05 which means the data are normally distributed. Test of normality was filled to run the homogeneity statistics and one-way ANAVA could be done. Test of homogeneity in this study used homogeneity of variance statistic model. self-awareness score was $p=0,118(p>0,05)$. It means that the data are homogenous. Then, the test of hypothesis was done to test the hypothesis of this study. There is the significant difference of self-awareness in LGBT actors in West Sumatera Province based in the Personality Typology'. The data were analyzed using one-way ANAVA $(\mathrm{F}=4.175 ; \mathrm{p}=0.03)$. it means that, Ha is accepted and there is the significant difference between self-awareness based on the personality typology (ambivalent, discordant, independent, dependent, detached) in LGBT actors in West Sumatera Province. 


\section{Discussion}

This study was conducted to people of LGBT in west Sumatera province, Indonesia. The study indicated that most participants have middle level of self-awareness $(66.96 \%)$ to high level $(33.04 \%)$. It means that most participants in certain situations can recognize and understand themselves and it allows them to interact effectively and behave as the environment wants. Behaviors are shown in introduction, understanding and consideration process to enable themn decide and show their behaviors based on the values and norms in society.

Goleman (2001) mentioned that a person with high self-awareness can recognize themselves and understand the impacts of their behaviors. Self-awareness has several aspect to enable assessing self: emotional awareness, self-concept, self-esteem and multiple-selves. The results of this study showed that the level of self-awareness is different among the aspects. Self concept developed better among the participants compared to other aspects. Self-concept is a must to have in order that a person can make a good decision [9]. Participants in this study have high level of self-concepts which is used to find happiness and developed to the proper relationship with their partners. Happiness and desire to develop relationship as the desire to be liked has become a factor to make people struggle to reach something. Emotional awareness, self-esteem) and multiple selves in participants develops well. Participants can recognize emotions in certain time and cannot do it in other situations. It indicates that the good emotional awareness is an indicator to recognize situation when emotion is felt related to feeling, mind and action which influence human performance [6]. Participants can evaluate self in distingushingg real self and ideal self. Feist \& Feist (2003) mentioned that self-esteem will describe how an individual wants to get power and self-confidence. Individual with high selfesteem tends to have higher self-confidence. Participants get more self-confidence for support from external environment like a community of LGBT who are willing to accept them. It is in line with the interview result which stated that peer, spouse, and community make them more confident. Baron and Byrne Donn (2004)stated that self-esteem playes important role in creating confidence. On the other hand, performing different self help participants use the proper role in social interaction. Sometimes, they cannot use the role well. Multiple selves refers to the role done continuously and reflected in life. It is a kind ways to do and amend self to enable adapting self in the environment effectively.

It can be inferred that participants need to enhance the three aspects of self-awareness: emotional-awareness, self-esteem and multiple selves. And, one aspect needs to continued to have better self-awareness. Leary (2012) stated that an individual with full self-awareness will conceptualize and evaluate self in order to find happiness and have good relationship with other in daily life. This study suggests that most participants have ambivalent personality typology $(49.5 \%)$, followed by independent $(20.1 \%)$, dependent $(15.2 \%)$, detached $(9.4 \%)$ and discordant (5.8\%). Millon (2011) defined ambivalent personality as the uncertainty of directions to change as the conflict of whether to be dependent or independent with others. In this context, this individual is in doubt to decide obeying other people or doing things happily in his own way. People in this typology are often bothere by the internal conflict in self [8]. Ambivalent personality is divided into three parts: active, passive and active-passive. Less than $84 \%$ of participants have passive ambivalent personality, $12.6 \%$ in passive-active, and $3.6 \%$ in active ambivalent personality.

Participants with passive ambivalent personality show the following traits: high obedience in rules and discipline, respectful in interpersonal relationship, polite, good character, well managed in cognitive style, have a diligent, trustworthy, efficient self-image, rigid in organizing something, relaxed in mood/temperament, uncontrolled emotion. 
Participants with active-passive ambivalent personality show the following traits: expressed actions tend to unknown, sudden unexpected energy followed by impulsivity and rudeness, difficulty to show attention and affection, anxiety to separation and isolation; fluctuative in perception and thinking. Memory is focused on the past experience, use regression as defense mechanism, under stress condition, deterioration occurs as the impact of inability to cope with conflict social wants. Confusion in imaging self image in the past and try to change performance through sad expressions, confusion in memories, the need for emotion, instability of emotion with external reality. Participants with active personality show the following traits: unwillingness to meet people's hope, procrastination, inefficiency, and manipulative. Conflicts in interpersonal relation; less tolerance with others, express negative attitudes. Cynical, doubt in looking at the future, do not trust positive events, negative worldview; displacement defense mechanism; feeling unlucky, not respected; Mood/Temperament tends to be Irritable, moody, talkactive The results suggest that there is significant difference of self-awareness based on personality typology in LGBT actors in West Sumatera Province, Indonesia. Most participants are in middle level of awareness of personality (ambivalent, discordant, independent, dependent, dan detached). Participants with ambivalent personality have middle level in emotional awareness and multiple selves, high level in selfconcept and self-esteem. Participants with discordant and independent personality have middle level in emotional awareness, self-esteem and multiple selves, high one in self-concept. Participants with dependent and detached personality have middle level of personality in all aspects.

\section{Conclussion}

It can be inferred from this study that:

1. Self-awareness level of LGBT actors in West Sumatera Province is in middle level. It indicates that they cannot recognize the best thing for themselves.

2. Most participants in this study have ambivalent personality with passive type of personality.

3. There is significant difference among the people of LGBT in West Sumatera province based on the personality typology.

LGBT people are suggested to enhance knowledge about their internal self. LGBT people behaviors are deviance in norms in society. Therefore, they need to match the real self and ideal self with social demands. Stakeholders are expected to design programs related to enhancement of self-awareness for LGBT and inform them.

\section{References}

[1] L. Garnet and D. c Kimmel, Psychological Perspectives On Lesbian , Gay, and Bisexual, Experiences. New York: Colombia University Press, 2003.

[2] J. W. Santrock, Adolescence "Perkembangan Remaja," 6th ed. JAkarta: Erlangga, 2003.

[3] J. S. Nevid, S. A. Rathus, and B. Greene, Psikologi Abnormal, 5th ed. Jakarta: Erlangga, 2003.

[4] R. P. Halgin and S. K. Whitbourne, Psikologi Abnormal (Perspektif Klinis pada Gangguan Psikologis). Jakarta: Salemba Humanika, 2010.

[5] R. L. Solso, O. H. Maclin, and M. K. Maclin, Psikologi Kognitif, 8th ed. Jakarta: Erlangga, 2007.

[6] D. Goleman, Emotional Intelligence: Why it can matter more than IQ. Jakarta: PT. Gramedia, 
2001.

[7] M. Afriani and R. Y. Primanita, "Hubungan Self Awareness dengan Adversity Quotient pada LGBT di Sumatera Barat," J. Ris. Psikol., vol. 2, 2019.

[8] T. Millon, Disorder Personality, 3rd ed. Canada: John Wiley \& Son, Inc, 2011.

[9] M. R. Leary, Self Awareness, Egotism and The Quality of Human Life. New York: Oxford University Press, 2012.

[10] J. Feist and G. J. Feist, Teori Kepribadian. Jakarta: Salemba Humanika, 2003.

[11] R. A. Baron and Byrne Donn, Psikologi Sosial. Jakarta: Erlangga, 2004. 